\title{
PENINGKATAN HASIL BELAJAR KETERAMPILAN MENJAHIT ROK MELALUI MEDIA MOCK UP DI KELAS TATA BUSANA SISWA SLB NEGERI 2 PADANG
}

\author{
Putri Ramadani ${ }^{*}$, Sri Zulfia Novrita ${ }^{2 *}$ \\ Program Studi Pendidikan Kesejahteraan Keluarga Jurusan Ilmu Kesejahteraan Keluarga \\ Fakultas Pariwisata dan Perhotelan \\ Universitas Negeri Padang \\ Jl. Prof. Dr. Hamta, Air Tawar Padang, Kel. Air Tawar Barat, Kec. Padang Utara, Kota Padang, Kode Pos 25171 \\ Sumatera Barat. Indonesia \\ Email:18Putriramadani@gmail.com
}

\begin{abstract}
Abstrak
Kurangnya hasil belajar siswa SLB N 2 Padang dalam pembelajaran menjahit rok disebabkan oleh media pembelajaran yang monoton sehingga membuat siswa kurang perhatian saat pembelajaran. Untuk itu dilakukan usaha peningkatan hasil belajar siswa pada pembelajaran menjahit rok dengan menggunakan media Mock Up. Penelitian ini adalah penelitian tindakan kelas yang dilakukan dalam dua siklus. Tiap siklus terdapat tiga kali pertemuan. Setiap siklus terdiri atas empat langkah yaitu perencanaan, pelaksanaan, observasi dan refleksi yang digunakan sebagai dasar dalam melakukan perbaikan pada siklus berikutnya. Pengumpulan data dalam penelitian ini dilakukan dengan menggunakan tes, observasi dan wawancara. Analisis data Menggunakan rumus persentase. Dengan demikian dapat disimpulkan bahwa melalui penggunaan media Mock Up memiliki dampak positif dalam meningkatkan Hasil Belajar Keterampilan Menjahit Di Kelas Tata Busana Siswa SLB Negeri 2 Padang. Hal ini dapat dilihat dari pemahaman dan penguasaan siswa terhadap materi yang telah disampaikan guru selama ini ketuntasan belajar meningkat dari Prasiklus, siklus I dan siklus II, yaitu masing-masing 33\%, 67\% dan 100\% dengan tindakan memberikan hadiah.
\end{abstract}

Kata Kunci: hasil belajar, media mock up.

\begin{abstract}
The lack of learning outcomes of extraordinary school country two Padang students in learning to sew a skirt is caused by monotonous learning media that makes students less attentive during learning. For this reason, an effort to improve student learning outcomes in learning to sew skirts using Mock Up media is done. This research is a classroom action research conducted in two cycles. Each cycle has three meetings. Each cycle consists of four steps, namely planning, implementation, observation and reflection which are used as the basis for making improvements in the next cycle. The instruments used were observation sheets, practical learning outcomes, and field notes. Data collection through the observation sheet was assisted by an observer. The data obtained were analyzed in two ways, namely qualitative data analyzed by narration and given quantitative arguments and data. Data analysis of researchers used a percentage formula Thus it can be concluded that through the use of media Mock Up has a positive impact in improving the Learning Outcomes of Sewing Skills in the Fashion Class of Students extraordinary school country two padang. This can be seen from students' understanding and mastery of the material delivered by the teacher so far the learning completeness has increased from Prasiklus, cycle I and cycle II, which are 33\%, 67\% and 100\% respectively by giving gifts.
\end{abstract}

Keywords: learning outcomes, media mock up

\section{PENDAHULUAN}

Dalam perkembangan pengetahuan dan teknologi pada zaman sekarang ini membawa perubahan pesat Pendidikan memegang peranan yang sangat penting bagi eksistensi dan kemajuan suatu bangsa atau negara. Maka setiap warga negara harus terus belajar dan meningkatkan kompetensinya agar dapat bersaing diera globalisasi ini. Di Negara Republik Indonesia sudah dijelaskan dalam Undang-Undang Dasar 1945 pasal 31 ayat 1 yang berbunyi "Setiap warga negara berhak mendapatkan pendidikan". Secara spesifik pada Undang-Undang nomor 20 tahun 2003 tentang Sistem Pendidikan Nasional dijelaskan tujuan pendidikan nasional adalah: "Pendidikan nasional berfungsi mengembangkan kemampuan dan membentuk watak serta peradaban bangsa yang 


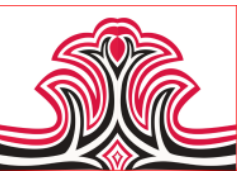

bermartabat dalam rangka mencerdaskan kehidupan bangsa, bertujuan untuk berkembangnya potensi siswa agar menjadi manusia yang beriman dan bertaqwa kepada Tuhan Yang Maha Esa, berakhlak mulia sehat, berilmu, cakap, kreatif.

Pemerintah memajukan ilmu pengetahuan dan teknologi dengan menjunjung tinggi nilai nilai agama dan persatuan bangsa untuk kemajuan peradapan kesejahteraan umat manusia (UUD 1945 Pasal 31 Ayat 5). Menurut UU Sisdiknas No. 20 Tahun 2003 Pasal 1 Ayat 1, Pendidikan adalah usaha sadar terencana untuk mewujudkan suasana belajar dan proses pembelajaran agar peserta didik secara aktif mengembangkan potensi dirinya untuk memiliki kekuatan spritual keagamaan, pengendalian diri, kepribadian, kecerdasan, akhlak mulia, serta keterampilan yang diperlukan dirinya, masyarakat, bangsa dan negara.

Undang-undang Republik Indonesia Nomor 20 Tahun 2003 tentang Sistem Pendidikan Nasional menyatakan bahwa pendidikan adalah usaha sadar dan terencana untuk mewujudkan suasana belajar dan proses pembelajaran agar peserta didik secara aktif mengembangkan potensi dirinya untuk memiliki kekuatan spiritual keagamaan, pengendalian diri, kepribadian, kecerdasan, akhlak mulia, serta keterampilan yang diperlukan dirinya, masyarakat, bangsa dan negara.

Sekolah Luar Biasa Negeri 2 Padang adalah lembaga pendidikan bagi anak berkebutuhan khusus yang berstatus negeri di Sumatera Barat, di SLB N 2 memberikan pendidikan keterampilan pada siswanya yang bertujuan untuk menunjang kemandirian anak yaitu pelajaran vokasional. Manfaatnya sebagai bekal dalam menghadapi serta memecahkan permasalahan baik secara pribadi, masyarakat dan sebagai warga negara. Jenis-jenis keterampilan yang dapat diberikan kepada ABK diantaranya ada tata busana, tata boga, tata rias dan komputer.Dari empat macam keterampilan yang dapat diberikan, SLB Negeri 2 Padangmemberikan keterampilan tata busana seperti menjahit yang diberikan pada siswa SMPLB.

Kurikulum pendidikan bagi anak dengan hambatan intelektual dalam memberi pelayanan pendidikan khusus pada jenjang pendidikan menengah dapat bermakna dalam kehidupan mereka, pada Renstra Direktorat PK-LK, Dikmen (2011-1014) dalam Cahyono (2015) menjelaskan bahwa Fokus kebijaksanaan pendidikan kewirausahaan bagi peserta didik, yang mengacu pada Permen Nomor 22
Gorga Jurnal Seni Rupa

Volume 08 Nomor 01 Januari-Juni 2019

p-ISSN: 2301-5942 | e-ISSN: 2580-2380

Tahun 2006 tentang standar isi untuk satuan pendidikan dasar dan menengah.

Berdasarkan hasil observasi awal yang dilakukan SLB Negeri 2 Padang, pelajaran keterampilan menjadi salah satu pelajaran yang harus diikuti oleh peserta didik tuna rungu dan tuna grita yang tergabung kedalam kelas tata busana. Salah satunya keterampilan yang diajarkan adalah keterampilan menjahit. Selama proses pembelajaran keterampilan menjahit selama ini guru hanya menggunakan media benda jadi sehingga siswa masih belajar secara monoton.

Dilihat pada nilai hasil belajar siswa yang nilainya kurang dari 65 atau belum mencapai KKM, hal ini menunjukkan bahwa masih terdapatnya kendala dalam proses pembelajaran keterampilan menjahit rok di SLB N 2. Dalam hal ini dapat dijelaskan bahwa masih terdapat kendala dalam proses pembelajaran keterampilan menjahit rok menggunakan media fragmen.

Berdasarkan kemukakan pendapat menurut Arief S. Sadiman (2003: 17-18) mengatakan bahwa secara umum media pendidikan mempunyai fungsi sebagai; a) Mengatasi keterbatasan ruang, waktu dan daya indera, b) Penggunaan media pendidikan secara tepat dan bervariasi dapat mengatasi sikap pasif anak didik, c) Sifat unik yang ada pada setiap siswa. bahwa Media pembelajaran merupakan alat untuk memproses pembelajaran sehingga memperoleh hasil pembelajaran yang lebih baik.

Oleh karena itu, berdasarkan masalah diatas, mak peneliti tertarik untuk melakukan sebuah penelitian tindakan kelas dengan judul penelitian adalah "Peningkatan Hasil Belajar Keterampilan Menjahit Melalui Media Mock Up Di Kelas Tata Busana Siswa SLB Negeri 2 Padang".

\section{KAJIAN TEORI}

\section{Belajar}

Menurut Suprijono (2012:3) Belajar sebagi konsep mendapatkan pengetahuan dalam praktiknya banyak dianut. Guru bertindak sebagai pengajar yang berusaha memberikan ilmu pengetahuan sebanyakbanyaknya dan peserta didik giat mengumpulkan atau menerimanya. Menurut Hariyanto (2011:9) Belajar adalah suatu aktivitas atau memperoleh, pengetahuan, meningkatkan keterampilan, memperbaiki perilaku, sikap dan mengokohkan kepribadian.

Berdasarkan beberapa pendapat para ahli tentang teori belajar, dapat disimpulkan bahwa belajar adalah sebagai proses atau kegiatan untuk mendapatkan pengetahuan dan pemahaman, meningkatkan 


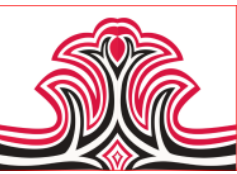

keterampilan, memperbaiki sikap dan perilaku sebagai hasil dari pengalaman sendiri dalam interaksi dengan lingkungan dan dapat merubah pola pikir maupun tingkah laku seseorang.

\section{Hasil Belajar}

Menurut Sudjana dan Rivai (2010: 22), hasil belajar adalah kemampuan yang dimiliki siswa setelah menerima pengalaman belajar. Selanjutnya Warsito (dalam Depdiknas, 2006: 125) mengemukakan bahwa hasil dari kegiatan belajar ditandai dengan adanya perubahan perilaku ke arah positif yang relatif permanen pada diri orang yang belajar. Sehubungan dengan pendapat itu, maka Wahidmurni, dkk. (2010: 18) menjelaskan bahwa sesorang dapat dikatakan telah berhasil dalam belajar jika ia mampu menunjukkan adanya perubahan dalam dirinya. Perubahanperubahan tersebut di antaranya dari segi kemampuan berpikirnya, keterampilannya, atau sikapnya terhadap suatu objek.

Dari beberapa pendapat para ahli di atas dapat disimpulkan bahwa hasil belajar adalah hasil dari suatu interaksi tindak belajar dan tindak mengajar dan merupakan usaha sadar yang dilakukan secara sistematis mengarah kepada perubahan yang positif yang meliputi kemampuan keterampilannya, atau sikapnya terhadap suatu objek.

\section{Keterampilan Menjahit}

Menjahit adalah pekerjaan menyambung kain, bulu, kulit binatang, atau bahan-bahan lain yang bisa dilewati jarum jahit dan benang. Menjahit dapat dilakukan dengan tangan memakai jarum tangan atau dengan mesin jahit. Keterampilan menjahit adalah kemampuan untuk mengeluarkan kreatifitas dalam upaya mengerjakan proses menyambung kain, bulu, kulit binatang, maupun bahan-bahan lain yang bisa dilewati jarum jahit dan benang. Keterampilan menjahit merupakan keterampilan yang sangat banyak diminati terutama oleh kaum wanita. Pengerjaan keterampilan ini hanya membutuhkan ketelitian dan kesabaran serta keuletan dalam menggunakan benang dan jarum serta alat-alat bantu lainnya.

\section{Media Pembelajaran}

Menurut Nunuk Suryani \& Leo Agung (2012: 43), "Yang dimaksud Media pembelajaran adalah segala sesuatu yang dapat digunakan sebagai alat bantu dalam rangka mendukung usaha-usaha pelaksanaan proses belajar-mengajar yang menjurus kepada pencapaian tujuan pembelajaran". Sedangkan menurut Heinich yang dalam Azhar Arsyad (2015: 4), "Media pembelajaran adalah perantara yang membawa pesan atau informasi bertujuan
Gorga Jurnal Seni Rupa

Volume 08 Nomor 01 Januari-Juni 2019

p-ISSN: 2301-5942 | e-ISSN: 2580-2380

instruksional atau mengandung maksud-maksud pengajaran antara sumber dan penerima”.

Berdasarkan beberapa pendapat para ahli di atas, dapat disimpulkan bahwa media pembelajaran adalah sebagai perantara atau pengantar yang digunakan untuk menyampaikan pesan pembelajaran yang dapat merangsang peserta didik dalam kegiatan belajar mengajar yang merupakan berbagai macam alat yang membantu pengajar dalam menyampaikan materi pembelajaran agar lebih mudah diterima oleh peserta didik.

\section{Media Maock Up}

Menurut Sudjana dan Rivai (2010:46) Media Mock Up adalah pecahan, penggalan sedikit-sedikit, memotong, menjadi kepingan. Mock Up yang dimaksudkan pada penelitian ini adalah langkah langkah dalam menjahit rok . Fungsi dari media itu sendiri adalah sebagai penyampai pesan kepada siswa. salah satu jenis media model tiga dimensi yang merupakan tiruan dari obyek nyata, seperti obyek yang terlalu besar, obyek yang terlalu jauh, obyek yang terlalu mahal, obyek yang terlalu kecil, atau obyek yang tidak memungkinkan dibawa ke kelas.

Berdasarkan pendapat beberapa ahli di atas, dapat disimpulkan bahwa Media Mock Up tiruan sederhana dari benda sebenarnya dimana sengaja dipilih bagianbagian yang memang penting dan yang diperlukan saja untuk dibuat sesederhana mungkin agar mudah dipelajari.

\section{METODE PENELITIAN}

Penelitian ini termasuk dalam jenis penelitian tindakan kelas (PTK). Penelitian ini dilaksanakan di SLB Negeri 2 Padang Kecamatan Koto Tangah. Waktu penelitian ini dilaksanakan semester genap tahun pelajaran 2018/2019, dimulai pada bulan Januari 2019. Subjek dalam penelitian ini adalah siswa kelas Tata busana SLB Negeri 2 Padang yang berjumlah 6 orang. Prosedur penelitian terdiri dari dua siklus dengan masing-masing siklus dua kali pertemuan. Setiap siklus terdiri atas empat tahap penelitian yaitu perencanaan, pelaksanaan, observasi dan refleksi. Pengumpulan data dalam penelitian ini dilakukan dengan menggunakan tes, observasi dan wawancara. Analisis data menggunakan rumus persentase.

\section{HASIL DAN PEMBAHASAN \\ 1.Hasil}

Dari hasil observasi awal, peneliti mendapatkan informasi tentang kondisi kelas pada saat kegiatan belajar berlangsung. Dalam mengajar guru masih menggunakan media pembelajaran bahan jadi. 
Kompetensi siswa dalam menjahit rok relatif rendah yang bisa terlihat table dibawah ini.

Tabel 1. Hasil Belajar Pra Siklus

\begin{tabular}{|c|c|c|c|}
\hline NO & $\begin{array}{l}\text { Nama } \\
\text { Siswa }\end{array}$ & Nilai & Keterangan \\
\hline 1 & $\mathrm{~A}$ & 65 & Tuntas \\
\hline 2 & B & 55 & Tidak Tuntas \\
\hline 3 & $\mathrm{C}$ & 50 & Tidak Tuntas \\
\hline 4 & $\mathrm{D}$ & 65 & Tuntas \\
\hline 5 & $\mathrm{E}$ & 50 & Tidak Tuntas \\
\hline 6 & $\mathrm{~F}$ & 50 & Tidak Tuntas \\
\hline \multicolumn{2}{|c|}{ Jumlah } & 335 & \\
\hline \multicolumn{2}{|c|}{ Rata-rata } & 55,85 & \\
\hline \multicolumn{2}{|c|}{ KKM } & 65 & \\
\hline
\end{tabular}

Tabel 2. Rekapitulasi Ketuntasan Belajar Siswa Pra Siklus

\begin{tabular}{|l|c|c|}
\hline \multicolumn{1}{|c|}{ Hasil Belajar } & Nilai/jumlah & Persentase \\
\hline $\begin{array}{l}\text { Jumlah Siswa Yang } \\
\text { Tuntas }\end{array}$ & 2 Orang & $33 \%$ \\
\hline $\begin{array}{l}\text { Jumlah Siswa Yang } \\
\text { Belum Tuntas }\end{array}$ & 4 Orang & $67 \%$ \\
\hline Jumlah Nilai & $\mathbf{3 3 5}$ & \multirow{2}{|}{} \\
\hline Rata-Rata & $\mathbf{5 5 , 8 5}$ & \\
\hline KKM & $\mathbf{6 5}$ &
\end{tabular}

Berdasarkan data dari tabel hasil penelitian pra siklus diatas, dari 6 siswa yang mengikuti pembelajaran menjahit rok menggunakan media papan tulis yang digunakan oleh guru menunjukkan bahwa siswa yang tuntas baru mencapai $33 \%$ siswa dan siswa yang belum tuntas $67 \%$ atau 4 siswa. Hal ini menunjukkan bahwa kompetensi siswa masih cukup rendah terlihat pada banyaknya siswa yang belum memenuhi kriteria tuntasan minimal.

\section{1).Siklus I}

\section{(1).Perencanaan}

Perencanaan penelitian dalam siklus I ini sebelum memulai pembelajaran, maka peneliti menyiapkan RPP, bahan ajar, Media pembelajaran yang dibutuhkan, lembar kerja siswa, lembar observasi dan dokumentasi yang akan dilakukan oleh observer untuk mengambil foto saat penelitian.

\section{(2).Pelaksanaan}

Pertemuan pertama siklus I dilaksanakan pada hari senin tanggal 4 Januari 2019 jam pelajaran 10:00 12:00 dikelas tata busana dengan jumlah siswa 6 orang.Pertemuan pertama siklus I dilaksanakan pada hari kamis tanggal 7 Januari 2019 jam pelajaran 10:00 - 12:00 dikelas tata busana dengan jumlah siswa 6 orang.

\section{(3).Observasi}

Gorga Jurnal Seni Rupa

Volume 08 Nomor 01 Januari-Juni 2019 p-ISSN: 2301-5942 | e-ISSN: 2580-2380

Tabel 3. Hasil Belajar Siklus I

\begin{tabular}{|c|c|c|c|}
\hline NO & $\begin{array}{l}\text { Nama } \\
\text { Siswa }\end{array}$ & Nilai & Keterangan \\
\hline 1 & $\mathrm{~A}$ & 70 & Tuntas \\
\hline 2 & $B$ & 65 & Tuntas \\
\hline 3 & $\mathrm{C}$ & 60 & Tidak Tuntas \\
\hline 4 & D & 70 & Tuntas \\
\hline 5 & $\mathrm{E}$ & 65 & Tuntas \\
\hline 6 & $\mathrm{~F}$ & 55 & Tindak Tuntas \\
\hline \multicolumn{2}{|c|}{ Jumlah } & 385 & \\
\hline \multicolumn{2}{|c|}{ Rata-rata } & 64,17 & \\
\hline \multicolumn{2}{|c|}{ KKM } & 65 & \\
\hline
\end{tabular}

Tabel 4. Rekapitulasi Ketuntasan Belajar Siswa Siklus I

\begin{tabular}{|l|c|c|}
\hline \multicolumn{1}{|c|}{ Hasil Belajar } & Nilai/jumlah & Persentase \\
\hline $\begin{array}{l}\text { Jumlah Sisuva Yang } \\
\text { Tuntas }\end{array}$ & 4 Orang & $67 \%$ \\
\hline $\begin{array}{l}\text { Jumlah Siswa Yang } \\
\text { Belum Tuntas }\end{array}$ & 2 Orang & $33 \%$ \\
\hline Jumlah Nilai & $\mathbf{3 8 5}$ & \multirow{2}{*}{$\mathbf{6 4 , 1 7}$} \\
\hline Rata-Rata & $\mathbf{6 5}$ & \\
\hline KKM & \multicolumn{2}{|l}{} \\
\cline { 1 - 2 } & &
\end{tabular}

Dari tabel di atas dapat dijelaskan bahwa setelah menerapkan media Mock-Up di peroleh rata - rata hasil belajar peserta didik yaitu 64,17 dengan presentase ketuntasan $67 \%$ atau 4 peserta didik dari 6 orang yang tuntas belajar. Sehingga masih terdapat $33 \%$ atau 2 orang lagi yang belum tuntas belajar. Hasil tersebut menunjukkan bahwa pada siklus I secara klasikal peserta didik sudah banyak yang tuntas belajar, namun ketuntasan yang dikehendaki belum mencapai target yang diinginkan sebesar $80 \%$ siswa yang tuntas.

\section{(4).Refleksi}

Berdasarkan hasil diskusi yang dilaksanakan pada hari jumat tanggal 8 Januari 2018 dengan observasi (Sonya Restiarizky S.Pd). Ada beberapa kelemahan yang dihadapi pada siklus pertama ini antara lain:Waktu yang kurang di kelola dengan baik sehingga melebihi batas waktu yang ditentukan.Ada siswa yang terkesan canggung dan masih ragu-ragu dalam menjahit rok melalui media Mock-Up.

Berdasarkan masalah tersebut, maka adapun jalan keluar yang akan dilaksanakan pada siklus berikutnya supaya tidak terjadi lagi masalah yang serupa adalah:Merancang waktu untuk penelitian dan pembelajaran yang lebih efektif.Menjelaskan terlebih dahulu sebelum pembelajaran ada itu media MockUp.Menyiapakan hadiah.

\section{2).Siklus 2}

\section{(1).Perencanaan}

Perencanaan penelitian dalam siklus II ini sebelum memulai pembelajaran, maka peneliti menyiapkan RPP, bahan ajar, Media pembelajaran yang 
dibutuhkan, lembar kerja siswa, lembar observasi dan dokumentasi yang akan dilakukan oleh observer untuk mengambil foto saat penelitian, dan menyiapkan hadiah.

\section{(2).Pelaksanaan}

Pertemuan pertama siklus II dilaksanakan pada hari Senin tanggal 11 Januari 2019 jam pelajaran 10:00 12:00 dikelas tata busana dengan jumlah siswa 6 orang.Pertemuan pertama siklus II dilaksanakan pada hari Rabu tanggal 20 Januari 2019 jam pelajaran 10:00 - 12:00 dikelas tata busana dengan jumlah siswa 6 orang.

\section{(3).Observasi}

Tabel 5. Hasil Belajar Siklus I

\begin{tabular}{|c|c|c|c|}
\hline No & $\begin{array}{l}\text { Nama } \\
\text { Siswa }\end{array}$ & Nilai & Keterangan \\
\hline 1 & A & 75 & Tuntas \\
\hline 2 & $B$ & 70 & Tuntas \\
\hline 3 & $\mathrm{C}$ & 65 & Tuntas \\
\hline 4 & $\mathrm{D}$ & 75 & Tuntas \\
\hline 5 & $\mathrm{E}$ & 70 & Tuntas \\
\hline 6 & $\mathrm{~F}$ & 65 & Tuntas \\
\hline \multicolumn{2}{|c|}{ Jumlah } & 420 & \\
\hline \multicolumn{2}{|c|}{ Rata-rata } & 70 & \\
\hline \multicolumn{2}{|c|}{ KKM } & 65 & \\
\hline
\end{tabular}

Tabel 6. Rekapitulasi Ketuntasan Belajar Siswa Siklus II

\begin{tabular}{|l|c|c|}
\hline \multicolumn{1}{|c|}{ Hasil Belajar } & Nilai/jumlah & Persentase \\
\hline $\begin{array}{l}\text { Iumlah Sisvas Yang } \\
\text { Tuntas }\end{array}$ & 6 Orang & $100 \%$ \\
\hline $\begin{array}{l}\text { Jumlah Siswa Yang } \\
\text { Belum Tuntas }\end{array}$ & 0 Orang & $0 \%$ \\
\hline Jumlah Nilai & $\mathbf{4 2 0}$ & \multicolumn{1}{|c}{0} \\
\hline Rata-Rata & $\mathbf{7 0}$ & \\
\cline { 1 - 2 } KKM & $\mathbf{6 5}$ &
\end{tabular}

Dari tabel di atas dapat dijelaskan bahwa setelah menerapkan media Mock-Up pada siklus II di peroleh rata - rata hasil belajarpeserta didik yaitu sudah mencapai 70 dengan presentase ketuntasan $100 \%$ atau 6 peserta didik dari 6 orang yang tuntas belajar. Hasil tersebut menunjukkan bahwa pada siklus II secara klasikal peserta didik sudah banyak yang tuntas belajar, namun ketuntasan yang dikehendaki belum mencapai target yang diinginkan sebesar $80 \%$ siswa yang tuntas.

\section{(4).Refleksi}

Berdasarkan hasil diskusi yang dilaksanakan pada hari kamis tanggal 21 Januari 2018 dengan observasi (Sonya Restiarizky S.Pd). Pada siklus II ini semua kendala yang ditemukan pada siklus sebelumnya sudah teratasi, waktu embelajaran sudah terkendali serta hasil belajar siswa sudah mencapai target yang diinginkan. Oleh karena itu penelitiann ini tidak perlu dilanjutkan ke siklus berikutnya.

\section{Pembahasan}

Tabel 7. Rekapitulasi Ketuntasan Belajar Siswa Siklus II

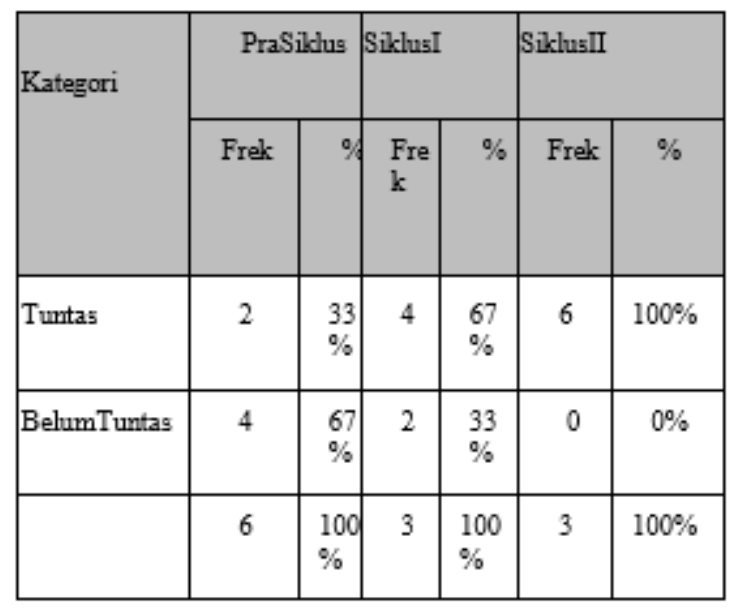

Berdasarkan data kompetensi dari 6 siswa yang mengikuti pembelajaran keterampilan menjahit rok melalui media Mock-Up dapat meningkatkan kompeten siswa sesuai yang diharapkan,dimana seluruh siswa 6 orang telah mencapai lebih dari KKM. Sesuai dengan ungkapan Pakar Pendidikan 2009 bahwa penerapan media Mock-Up melibatkan siswa berperan aktif dan dapat mengatasi kebosanan siswa terhadap metode pembelajaran yang biasa digunakan oleh guru, sehingga timbul kesenangan dari diri siswa pada saat kegiatan pembelajaran.

peningkatan hasil belajar siswa, yang terlihat dari jumlah siswa yang tuntas yaitu siswa yang memperoleh nilai 65 keatas (sesuai dengan kriteria keberhasilan tindakan) ada 4 orang dengan persentase $67 \%$ pada siklus 1 menjadi 6 orang pada siklus 2 dengan persentase $100 \%$. Pada siklus 1, persentase jumlah siswa yang sudah tuntas adalah $100 \%$,

Bisa dilihat Pendapat pendapat Sudjana dan Rivai (2010:46) Media Mock Up adalah pecahan, penggalan sedikit-sedikit, memotong, menjadi kepingan. Mock Up yang dimaksudkan pada penelitian ini adalah langkah - langkah dalam menjahit rok. Fungsi dari media itu sendiri adalah sebagai penyampai pesan kepada siswa. Salah satu jenis media model tiga dimensi yang merupakan tiruan dari obyek nyata, seperti obyek yang terlalu besar, obyek yang terlalu jauh, obyek yang terlalu mahal, obyek yang terlalu kecil, atau obyek yang tidak memungkinkan dibawa ke kelas.

Menurut Sanaky (2011:114) adapun kelebihan dari penggunaan Media Mock Up, diantaranya:“(a) memberikan pengalaman langsung terhadap obyek yang rumit untuk dipelajari benda nyatanya, (b) menunjukan struktur obyek secara jelas, (c) 


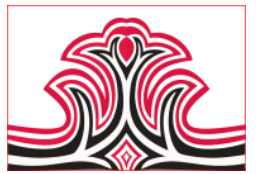

menunjukan alur kerja suatu obyek secara jelas, (d) menyederhanakan obyek yang sulit dibawa ke kelas".

Berdasarkan hasil penelitian terhadap kompetensi siswa data diperoleh berdasarkan ranah afektif, ranah kognitif, dan ranah psikomotor yang diperoleh siswa melalui penilaian unjuk kerja dari pra siklus, siklus I dan siklus II. Penghitungan penilaian pada kompetensi belajar siswa dalam membuat macam-macam pola rok.

\section{KESIMPULAN DAN SARAN}

\section{Kesimpulan}

Sesuai dengan rumusan masalah dan tujuan penelitian yang telah dikemukakan tentang penggunaan Media Mock Up pada mata pelajaran menjahir memberikan dampak positif. Jadi dapat disimpulkan dengan Media Mock Up ini dapat meningkatkan hasil belajar menjahit siswa di kelas tata busana SLB Negeri 2 Padang dengan tindakan memberikan hadiah.

\section{Saran}

Berdasarkan temuan penelitian disarankan kepada seluruh guru keterampilan di SLB N 2 Padang untuk dapat melanjutkan penggunaan media Moc-Up dalam keterampilan menjahit rok. Serta kepada peneliti selanjutnya agar dapat mencari media lainnya untuk dapat meningkatkan keterampilan siswa tunarungu. Sehingga siswa tunarungu dapat mengembangkan potensi yang ada pada dirinya.

\section{DAFTAR RUJUKAN}

Agus, Suprijono. (2012). Metode dan Model-Model Mengajar. Bandung: Alfabeta.

Dinas Pendidikan Sumatera Barat, 2013. Kurikulum Tata Busana SLB 2 Padang Sumatera Barat Sekolah Luar Biasa. Padang: Dinas Pendidikan Sumatera Barat.

Haryanto, Suryono (2011). Belajar dan Pembelajaran Teori dan Konsep Dasar. Bandung: PT Remaja Rosdakarya.

Arsyad, Azhar. (2015). Media Pembelajaran. Jakarta: PT Raja Grafindo Persada.

Nunuk Suryani dan Leo Agung. (2012). Strategi Belajar Mengajar. Yokyakarta: Ombak

Sanaky. (2011). Media Pembelajaran.Jakarta: Erlangga.

Sri Zulfia Novrita \& Ramainas. (2007). Peningkatan Motivasi belajar Melalui Media Pembelajaran pada mata kuliah Busana Pria (Action Reseach) dijurusan Kesejahteraan Keluarga FT UNP. No.26/Maret 2007.

Sudjana \& Rivai, (2010), Media Pembelajaran (penggunmaan dan pembuatannya). Bandung: Sinar Baru.

Warsinto Dalam Depdiknas (2006). Bunga Rumpai Keberhasilan Guru Dalam Pembelajaran (SMK, SMK, dan SLB). Jakarta: Depdiknas.
Gorga Jurnal Seni Rupa

Volume 08 Nomor 01 Januari-Juni 2019

p-ISSN: 2301-5942 | e-ISSN: 2580-2380

Wahidmurni. (2010). Pembelajaran Ilmu Penetahuan Sosial Terpadu Pada Satuan Pendidikan Mi/S Dan Mts/Smp. Http://Tarbiyah.UinMalang.ac.id. Diakses. 